Prepared for the U.S. Department of Energy under Contract DE-AC05-76RL01830

\title{
Comparison of 2006 IECC and 2009 IECC Commercial Energy Code Requirements for Kansas City, MO
}

\author{
Y Huang \\ K Gowri
}

March 2011

\section{Pacific Northwest}

NATIONAL LABORATORY

Proudly Operated by Battelle Since 1965 


\section{DISCLAIMER}

This report was prepared as an account of work sponsored by an agency of the United States Government. Neither the United States Government nor any agency thereof, nor Battelle Memorial Institute, nor any of their employees, makes any warranty, express or implied, or assumes any legal liability or responsibility for the accuracy, completeness, or usefulness of any information, apparatus, product, or process disclosed, or represents that its use would not infringe privately owned rights. Reference herein to any specific commercial product, process, or service by trade name, trademark, manufacturer, or otherwise does not necessarily constitute or imply its endorsement, recommendation, or favoring by the United States Government or any agency thereof, or Battelle Memorial Institute. The views and opinions of authors expressed herein do not necessarily state or reflect those of the United States Government or any agency thereof.

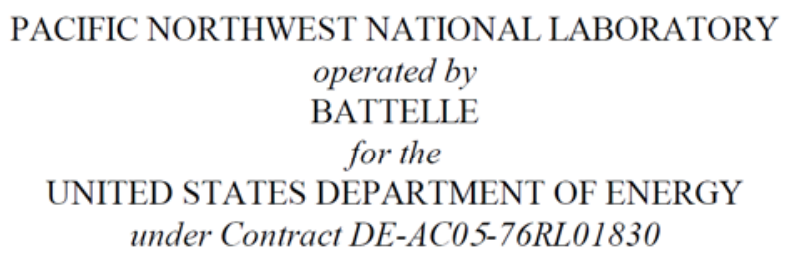

Printed in the United States of America

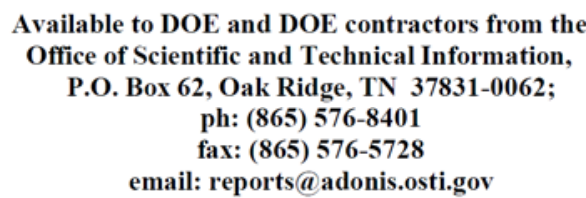

Available to the public from the National Technical Information Service, U.S. Department of Commerce, 5285 Port Royal Rd., Springfield, VA 22161 ph: (800) 553-6847 fax: (703) 605-6900

email: orders@ntis.fedworld.gov

online ordering: http://www.ntis.gov/ordering.htm

This document was printed on recycled paper. 
Comparison of 2006 IECC and 2009 IECC Commercial Energy Code Requirements for Kansas City, MO

Y Huang

K Gowri

March 2011

Prepared for

U.S. Department of Energy

under Contract DE-AC05-76RL01830

Pacific Northwest National Laboratory

Richland, Washington 99352 



\section{Executive Summary}

This report summarizes code requirements and energy savings of commercial buildings in Climate Zone 4 built to the 2009 IECC when compared to the 2006 IECC.

In general, the 2009 IECC has higher insulation requirements for exterior walls, roof, and windows and has higher efficiency requirements for heating, ventilation and air-conditioning (HVAC) equipment. HVAC equipment efficiency requirements are governed by the National Appliance Energy Conservation Act of 1987 (NAECA), and are applicable irrespective of the IECC version adopted.

The energy analysis results show that residential and nonresidential commercial buildings meeting the 2009 IECC requirements save $9.0 \%$ and $6.1 \%$ site energy, and $7.7 \%$ and $6.4 \%$ energy cost when compared to the 2006 IECC. Analysis also shows that semiheated buildings have energy and cost savings of $3.9 \%$ and $2.5 \%$. 


\section{Table of Contents}

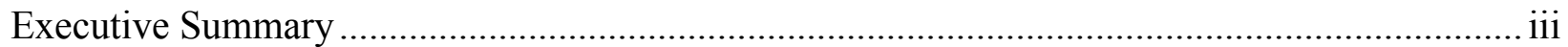

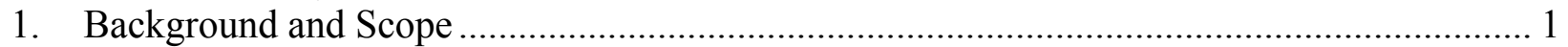

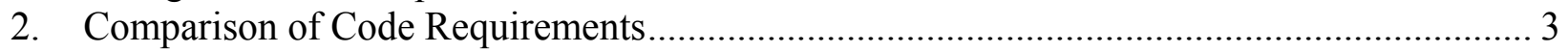

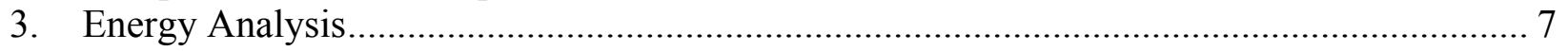

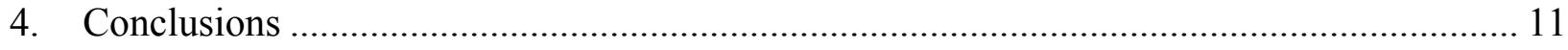

Appendix A - Detailed Comparison of Code Requirements .............................................. A.1

Appendix B - Prototype Building Descriptions ................................................................... 1 


\section{Tables}

Table 1: Comparison of Envelope Requirements ................................................................. 5

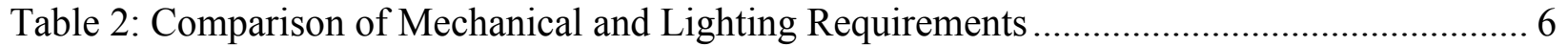

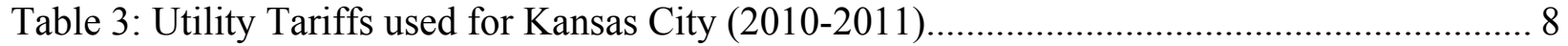

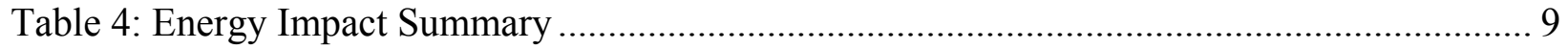

Table 5: Utility Cost and Environmental Impact Summary ................................................ 9

Table 6: Energy, Utility Cost and Environmental Reduction (percentage) ............................. 11

Table A.1: Comparison of Code Requirements ............................................................... A.1

Table B.1: Residential Prototype Building Characteristics ................................................. 1

Table B.2: Non-residential Prototype Building Characteristics ........................................... 3

Table B.3: Semi-heated Prototype Building Characteristics .....................................................5 


\section{Background and Scope}

Kansas City, MO is considering the adoption of the 2009 IECC and requested the assistance of DOE's Building Energy Codes Program to determine energy savings and environmental impact of adopting the 2009 IECC compared to the 2006 IECC. The analysis set the 2006 IECC as the baseline, because it is the currently enforced energy code in Missouri.

The following three building types were chosen for energy simulation and analysis:

1. Multifamily residential: Mid-rise apartment building

2. Nonresidential: Medium office building

3. Semi-heated: Industrial office/warehouse building

Department of Energy (DOE) Commercial Reference Building Models ${ }^{a}$ for the above building types were adapted for the analysis. The analysis study was conducted by using the EnergyPlus simulation tool, and the original models were modified to meet the envelope, lighting and mechanical requirements of the 2006 IECC, and the 2009 IECC, correspondingly. Typical meteorological year 2 (TMY2) weather data for Kansas City was chosen to run the simulation.

This report focuses on the comparisons of code requirements and energy analysis results for the above building types in Climate Zone 4. In addition to energy savings estimates, the analysis also includes annual energy cost and $\mathrm{CO}_{2}$ emissions estimates. This study does not address cost effectiveness or payback for the additional cost of complying with the 2009 IECC.

${ }^{a}$ http://www1.eere.energy.gov/buildings/commercial_initiative/reference_buildings.html 


\section{Comparison of Code Requirements}

The commercial code requirements in the 2006 IECC and the 2009 IECC for envelope, mechanical and lighting systems are listed in Tables 1 and 2. The envelope insulation and fenestration requirements for Kansas City, MO are specified in the 2009 IECC Tables 502.1.2, 502.2 and 502.3 for Climate Zone 4 (except Marine), representing the requirements for Jackson County (Climate Zone 4A). The scope of comparison is limited to building characteristics that can be modeled for detailed energy simulation and analysis. The 2009 IECC includes a number of significant changes to commercial building requirements in Chapter 5. The most important changes include the introduction of the envelope U-factor table, Group R specific envelope requirements, HVAC minimum efficiency requirements, economizer requirements, pipe insulation requirements and exterior lighting requirements. Appendix-A provides a detailed comparison of all the changes between the 2006 IECC and 2009 IECC Chapter 5.

A qualitative summary of the 2009 IECC changes are listed below:

- Alternative compliance using ASHRAE/IESNA 90.1 requires the use of 90.1-2007 (instead of 90.1-2004).

- More stringent envelope requirements are included for "Group R" buildings, in addition to more stringent opaque envelope requirements for all commercial buildings in all climate zones.

- The opaque requirements for roof, above-grade walls and floors are more stringent in the 2009 IECC, but the below grade wall assemblies and fenestration requirements remain the same as 2006 IECC.

- Metal building insulation requirements have been revised to be more stringent and require mandatory continuous insulation sheathing on metal building walls.

- Plastic skylights requirements are removed and all skylights are required to meet more stringent U-factor and solar heat gain coefficient (SHGC) requirements.

- All recessed lighting is required to be IC-rated and sealed.

- HVAC equipment efficiency requirements for unitary air conditioners, chilled water systems and boilers have been revised to be more stringent. The minimum efficiency requirements for unitary air-conditioners is seasonal energy efficiency rating (SEER) 13.0 for the 2009 IECC compared to SEER 10.0 in the 2006 IECC. (These are based on NAECA requirements and are applicable irrespective of the version of IECC adopted.)

- Piping insulation requirements have been revised and $1 \frac{1}{2}$ inch insulation is required for all pipes with nominal pipe diameter less than or equal to $1 \frac{1 / 2}{2} \mathrm{inch}$.

- A new fan power requirements section has been added and fan power limitations are included.

- Economizer requirements have been revised to require economizers when cooling capacity exceeds $54 \mathrm{kBtu} / \mathrm{h}$ in all climate zones except 1,2A, 7 and 8. 
- Heat rejection equipment requirements have been revised based on climate zone, and a new exception is provided if a heat pump is used to reject heat throughout the year.

- A new requirement has been added for supply-air temperature reset controls to reset the supply air temperature based on building loads or outdoor air temperature.

- Lighting exemption for dwelling units is provided if high-efficacy lamps are used in at least $50 \%$ of all the permanent fixtures.

- A new section has been added requiring manual daylight zone controls in zones adjacent to vertical fenestration and zones with skylights.

- The interior lighting power requirements exemption list has been revised and expanded to specify more detailed functions such as photographic process, lighting in refrigerator/ freezer cases, and furniture-mounted task lighting that is controlled by automatic shut off.

- Interior lighting power allowance adjustments have been revised for retail display based on the type of products on display.

- Lighting-zone-based power allowance requirements are specified for exterior lighting. 
Table 1: Comparison of Envelope Requirements

\begin{tabular}{|c|c|c|c|c|c|}
\hline \multicolumn{5}{|c|}{ Kansas City, MO [Climate Zone 4 (except Marine)] } & \multirow{2}{*}{$\begin{array}{l}\text { Change } \\
\text { captured in } \\
\text { the model }\end{array}$} \\
\hline Section & Sub-category & 2006 IECC & \multicolumn{2}{|l|}{2009 IECC } & \\
\hline \multicolumn{6}{|l|}{502 Envelope } \\
\hline \multicolumn{2}{|c|}{ 502.2 Specific insulation requirements } & & All other & Group R & \multirow[b]{2}{*}{ Yes } \\
\hline Roofs & $\begin{array}{l}\text { Insulation entirely above deck } \\
\text { Metal } \\
\text { Attic and other }\end{array}$ & $\begin{array}{l}\text { U-0.063 } \\
\text { U-0.065 } \\
\text { U-0.034 }\end{array}$ & $\begin{array}{l}\text { U-0.048 } \\
\text { U-0.055 } \\
\text { U-0.027 }\end{array}$ & $\begin{array}{l}\text { U-0.048 } \\
\text { U-0.055 } \\
\text { U-0.027 }\end{array}$ & \\
\hline Above-grade wall & $\begin{array}{l}\text { Mass } \\
\text { Metal building } \\
\text { Metal framed } \\
\text { Wood framed and other }\end{array}$ & $\begin{array}{r}\text { U-0.151 } \\
\text { U-0.124 } \\
\text { U-0.124 } \\
\text { U-0.124 }\end{array}$ & $\begin{array}{r}\text { U-0.104 } \\
\text { U-0.084 } \\
\text { U-0.064 } \\
\text { U-0.089 }\end{array}$ & $\begin{array}{c}\text { U-0.09 } \\
\text { U-0.084 } \\
\text { U-0.064 } \\
\text { U-0.064 }\end{array}$ & Yes \\
\hline Below-grade wall & Below-grade wall & $\mathrm{C}-1.14$ & $\mathrm{C}-1.14$ & C-0.119 & No \\
\hline Floors & $\begin{array}{l}\text { Mass } \\
\text { Joist/framing steel/(wood) }\end{array}$ & $\begin{array}{l}\text { U-0.087 } \\
\text { U-0.052 }\end{array}$ & $\begin{array}{l}\text { U-0.087 } \\
\text { U-0.033 }\end{array}$ & $\begin{array}{l}\text { U-0.074 } \\
\text { U-0.033 }\end{array}$ & Yes \\
\hline $\begin{array}{l}\text { Slab-on-grid } \\
\text { floors }\end{array}$ & $\begin{array}{l}\text { Unheated slab } \\
\text { Heated slab }\end{array}$ & $\begin{array}{l}\text { F-0.73 } \\
\text { F-1.02 }\end{array}$ & $\begin{array}{l}\text { F-0.73 } \\
\text { F-0.68 }\end{array}$ & $\begin{array}{l}\text { F-0.54 } \\
\text { F-0.86 }\end{array}$ & Yes \\
\hline Opaque doors & $\begin{array}{l}\text { Swinging } \\
\text { Roll-up or sliding }\end{array}$ & $\begin{array}{l}\text { U-0.70 } \\
\text { U-1.45 }\end{array}$ & $\begin{array}{l}\mathrm{U}-0.70 \\
\mathrm{U}-0.50\end{array}$ & $\begin{array}{l}\mathrm{U}-0.7 \\
\mathrm{U}-0.5\end{array}$ & Yes \\
\hline \multicolumn{6}{|l|}{ 502.3 Fenestration } \\
\hline \multirow[t]{2}{*}{$\begin{array}{l}\text { Vertical } \\
\text { fenestration } \\
(<40 \%)\end{array}$} & $\begin{array}{l}\text { Framing other than metal } \\
\text { Metal framing - curtain } \\
\text { Wall/storefront } \\
\text { Metal framing - entrance door } \\
\text { Metal framing - All other }\end{array}$ & $\begin{array}{l}\mathrm{U}-0.4 \\
\mathrm{U}-0.50 \\
\mathrm{U}-0.85 \\
\mathrm{U}-0.55\end{array}$ & $\begin{array}{l}\text { U-0.4 } \\
\text { U-0.50 } \\
\text { U-0.85 } \\
\text { U-0.55 }\end{array}$ & $\begin{array}{l}- \\
- \\
- \\
-\end{array}$ & Yes \\
\hline & $\begin{array}{l}\mathrm{PF}<0.25 \\
0.25<=\mathrm{PF}<0.5 \\
\mathrm{PF}>=0.5\end{array}$ & $\begin{array}{l}\text { SHGC-0.4 } \\
\text { SHGC-NR } \\
\text { SHGC-NR }\end{array}$ & $\begin{array}{l}\text { SHGC-0.4 } \\
\text { SHGC-NR } \\
\text { SHGC-NR }\end{array}$ & $\begin{array}{l}- \\
-\end{array}$ & Yes \\
\hline \multicolumn{6}{|l|}{$\begin{array}{l}\text { 502.4 Air } \\
\text { Leakage }\end{array}$} \\
\hline \multirow{3}{*}{$\begin{array}{l}502.4 .4 \text { Hot gas } \\
\text { bypass limitation }\end{array}$} & $<=90 \mathrm{kBtu} / \mathrm{h}$ & NA & Max hot gas & city: excepted & \multirow{3}{*}{ No } \\
\hline & $>90 \mathrm{kBtu} / \mathrm{h}$ and $<=240 \mathrm{kBtu} / \mathrm{h}$ & NA & Max hot gas & city: $50 \%$ & \\
\hline & $>240 \mathrm{kBtu} / \mathrm{h}$ & NA & Max hot gas & city: $25 \%$ & \\
\hline $\begin{array}{l}\text { 502.4.7 Recessed } \\
\text { luminaires }\end{array}$ & & $\begin{array}{l}\text { non-IC rated } \\
\text { fixture } \\
\text { allowed }\end{array}$ & All fixtures s & e IC-rated & No \\
\hline $\begin{array}{l}502.5 \text { Moisture } \\
\text { control }\end{array}$ & & $\begin{array}{l}\text { vapor retarder } \\
\text { required }\end{array}$ & NA & & No \\
\hline
\end{tabular}


Table 2: Comparison of Mechanical and Lighting Requirements

\begin{tabular}{|c|c|c|c|c|c|}
\hline \multicolumn{5}{|c|}{ Kansas City, MO [Climate Zone 4 (except Marine)] } & \multirow{2}{*}{$\begin{array}{c}\text { Change } \\
\text { captured } \\
\text { in the } \\
\text { model }\end{array}$} \\
\hline Section & Sub-category & 2006 IECC & \multicolumn{2}{|c|}{2009 IECC } & \\
\hline \multicolumn{6}{|c|}{503 Mechanical } \\
\hline \multicolumn{6}{|c|}{ 503.2.3 HVAC equipment performance requirements } \\
\hline $\begin{array}{l}\text { Unitary AC, } \\
\text { electrical }\end{array}$ & $\begin{array}{l}<65 \mathrm{kBtu} / \mathrm{h} \text { Single package } \\
<65 \mathrm{kBtu} / \mathrm{h} \text { Split } \\
>=65 \mathrm{kBtu} / \mathrm{h} \&<135 \mathrm{kBtu} / \mathrm{h} \\
>=135 \mathrm{kBtu} / \mathrm{h} \&<240 \mathrm{kBtu} / \mathrm{h} \\
>=240 \mathrm{kBtu} / \mathrm{h} \&<760 \mathrm{kBtu} / \mathrm{h} \\
>760 \mathrm{kBtu} / \mathrm{h}\end{array}$ & $\begin{array}{l}\text { 10.0 SEER } \\
\text { 9.7 SEER } \\
\text { 10.3 EER } \\
\text { 9.7 EER } \\
\text { 9.5 EER } \\
\text { 9.2 EER }\end{array}$ & $\begin{array}{l}\text { 13.0 SEER } \\
13.0 \mathrm{SEER} \\
11.2 \mathrm{EER} \\
11.0 \mathrm{EER} \\
10.0 \mathrm{EER} \\
\text { 9.7 EER }\end{array}$ & $\begin{array}{l}- \\
- \\
- \\
- \\
- \\
-\end{array}$ & Yes \\
\hline $\mathrm{DCV}$ & $\begin{array}{l}\text { Space }>500 \mathrm{sqft}+ \\
40 \text { person } / 1000 \text { sqft at average }\end{array}$ & NA & \multicolumn{2}{|c|}{ Required +1 of 3 systems } & No \\
\hline ERV & $\begin{array}{l}\text { Fan }>=5000 \mathrm{cfm}+70 \% \mathrm{~min} \\
\text { fraction }\end{array}$ & ERV+exception & \multicolumn{2}{|c|}{ ERV+different exception } & No \\
\hline \multicolumn{6}{|c|}{ 503.2.10 Air system design and control } \\
\hline & Fan motor $>5 \mathrm{hp}$ & NA & \multicolumn{2}{|c|}{$\begin{array}{l}\text { CAV: } \mathrm{hp}<=\mathrm{cfm}^{*} 0.0011 \\
\text { VAV: } \mathrm{hp}<=\mathrm{cfm} * 0.0015\end{array}$} & No \\
\hline \multicolumn{6}{|l|}{505 Lighting } \\
\hline \multicolumn{6}{|c|}{505.5 Interior lighting power requirements } \\
\hline & Lighting Power Density & & \multicolumn{2}{|c|}{$\begin{array}{l}\text { Allows additional interior } \\
\text { lighting power }\end{array}$} & No \\
\hline \multicolumn{6}{|c|}{ 505.6 Exterior lighting } \\
\hline & & $1 \mathrm{bin}$ & $\begin{array}{l}4 \text { exterior } \\
\text { lighting zones: } \\
\text { Zone } 3 \text { used } \\
\text { for non- } \\
\text { residential }\end{array}$ & $\begin{array}{l}4 \text { exterior } \\
\text { lighting } \\
\text { zones: } \\
\text { Zone } 4 \text { used } \\
\text { for } \\
\text { residential }\end{array}$ & Yes \\
\hline
\end{tabular}




\section{Energy Analysis}

The impact of code requirements is quantified by analyzing building models representing the envelope, lighting and mechanical requirements identified in the comparison Tables 1 and 2. DOE Reference Building models for four representative building types were used for the analysis. A brief description of each of the building type is below:

1. Residential - Multifamily/Midrise apartment building (33,700 sf): This is a fourstory building with $15 \%$ window-wall ratio. This building is assumed to have steel frame walls, metal deck rook with insulation above deck and a slab-on-grade floor. Each apartment unit is assumed to have a packaged air-conditioning unit with a gas furnace and a 20-gallon electric service water heating system. More details of the thermal model with the baseline properties are listed in Appendix-A, Table A-1.

2. Nonresidential - Medium office building (53,600 sf): This is a three-story building with $33 \%$ window-wall ratio. This building is assumed to have steel frame walls, metal deck rook with insulation above deck and a slab-on-grade floor. The HVAC system is a multi-zone VAV system with electric reheat, and packaged air-conditioner with gas furnace. Service water heating is assumed to be 260-gallon gas water heating. Further details on the energy model are provided in Appendix-A, Table A-2.

3. Semiheated - Large warehouse building (52,045 sf): This is a non-refrigerated warehouse building with an office area, fine storage and bulk storage areas. This building is assumed to have metal building walls, metal deck rook with insulation above deck and a slab-on-grade floor. The office area is conditioned by a packaged airconditioning unit with a gas furnace, and the storage areas are heated with a natural gas unit heater. Service water heating is assumed to be a 20 -gallon electric storage water heater.

Hourly energy simulation of the building model was performed for each of codes: the 2006 IECC and the 2009 IECC. EnergyPlus simulation software was used for the analysis. A typical design day simulation was done to determine the HVAC equipment size and then the annual simulation was run to determine the building energy use. The total building site energy is extracted from the simulation results for code comparisons.

To assess the economic impacts of the code requirements, current utility tariffs for Kansas City ${ }^{b}$ are used to calculate the total annual energy cost. Table 3 shows the fuel prices, demand charges and rate structure used, assuming a basic rate plan.

\footnotetext{
${ }^{\mathrm{b}}$ http://www.ameren.com/sites/aue/MyHome/ResidentialRates/Pages/default.aspx http://www.ameren.com/sites/aue/MyBusiness/BusinessRates/Pages/Businessrates.aspx
} 
Table 3: Utility Tariffs used for Kansas City (2010-2011)

\begin{tabular}{|c|c|c|c|}
\hline \multicolumn{4}{|c|}{ Utility Tarrif } \\
\hline \multirow{5}{*}{ Residential } & \multirow{4}{*}{ Energy Charge } & Electricity & Gas \\
\hline & & Monthly Charge: $\$ 16.81 / \mathrm{mo}$ & \multirow{3}{*}{$\begin{array}{l}\text { Monthly charge: } \$ 15.00 / \text { mo } \\
<30 \text { Therm: } \$ 0.7952 / \text { Therm } \\
\text { >30 Therm: } \$ 0 / \text { Therm }\end{array}$} \\
\hline & & $\begin{array}{l}\text { Summer: } \\
\text { On-peak: } 14.06 \text { cents/kWh } \\
\text { Off-peak: } 5.76 \text { cents/kWh }\end{array}$ & \\
\hline & & $\begin{array}{l}\text { Winter: } \\
\text { On-peak: } 8.3 \text { cents/kWh } \\
\text { Off-peak: } 4.1 \text { cents/kWh }\end{array}$ & \\
\hline & Demand Charge & NA & NA \\
\hline \multirow{6}{*}{ Commercial } & \multirow{5}{*}{ Energy Charge } & Electricity & Gas \\
\hline & & Monthly Charge: $\$ 96.23 / \mathrm{mo}$ & Monthly Charge: $\$ 28.83 / \mathrm{mo}$ \\
\hline & & $\begin{array}{l}\text { Summer: } \\
\text { <150 kWh: } 8.89 \text { cents/kWh } \\
\text { next } 200 \text { kWh: } 6.69 \text { cents/kWh }\end{array}$ & \multirow[t]{3}{*}{$\begin{array}{l}<7000 \text { Therm: } \$ 0.3089 / \text { Therm } \\
\text { >7000 Therm: } \$ 0.2023 / \text { Therm }\end{array}$} \\
\hline & & $\begin{array}{l}>350 \text { kWh: } 4.50 \text { cents/kWh } \\
\text { Summer Adjustment: } \\
\text { On-peak: }+1.05 \text { cents/kWh } \\
\text { Off-peak: }-0.59 \text { cents/kWh }\end{array}$ & \\
\hline & & $\begin{array}{l}\text { Winter } \\
\quad<150 \text { kWh: } 5.60 \text { cents/kWh } \\
\text { next } 200 \text { kWh: } 4.15 \text { cents/kWh } \\
\text { >350 kWh: } 3.26 \text { cents/kWh } \\
\text { Winter Adjustment: } \\
\text { On-peak: }+0.32 \text { cents/kWh } \\
\text { Off-peak: }-0.18 \text { cents/kWh }\end{array}$ & \\
\hline & Demand Charge & $\begin{array}{ll}\text { Summer: } & \$ 4.15 / \mathrm{kW} \\
\text { Winter: } & \$ 1.54 / \mathrm{kW}\end{array}$ & NA \\
\hline
\end{tabular}

In addition to calculating the annual energy consumption and cost savings, the analysis also includes estimates for carbon emissions based on state-average $\mathrm{CO}_{2}$ emission factors available in the EnergyPlus data set. For the state of Missouri, $\mathrm{CO}_{2}$ emission factors assumed are: 50.23 $\mathrm{g} / \mathrm{MJ}$ for natural gas and $192.02 \mathrm{~g} / \mathrm{MJ}$ for electricity. 
The energy simulation results are summarized in Table 4 for all the building types analyzed in this study. This summary includes total annual electricity consumption, natural gas consumption, annual energy cost and $\mathrm{CO}_{2}$ emissions. It can be observed that the overall savings is significantly higher for residential construction than nonresidential or semi-heated buildings. This can be attributed to the increased insulation requirements for above-grade envelope components for residential buildings in the 2009 IECC.

Table 4: Energy Impact Summary

\begin{tabular}{|l|c|c|c|c|c|c|}
\hline \multicolumn{3}{|c|}{ Energy Impact } \\
\hline \multirow{3}{*}{$\begin{array}{l}\text { Building } \\
\text { Prototype }\end{array}$} & \multicolumn{7}{|c|}{ Energy Use Intensity (EUI) } \\
\cline { 2 - 7 } & \begin{tabular}{c} 
2006 IECC \\
Electricity \\
\cline { 2 - 7 }
\end{tabular} & $\begin{array}{c}\text { Natural Gas } \\
(\mathrm{kBtu} / \mathrm{sf} / \mathrm{yr})\end{array}$ & $\begin{array}{c}\text { EUI } \\
(\mathrm{kBtu} / \mathrm{sf} / \mathrm{yr})\end{array}$ & $\begin{array}{c}\text { Electricity } \\
(\mathrm{kWh} / \mathrm{sf} / \mathrm{yr})\end{array}$ & $\begin{array}{c}\text { Natural Gas } \\
(\mathrm{kBtu} / \mathrm{sf} / \mathrm{yr})\end{array}$ & $\begin{array}{c}\text { EUI } \\
(\mathrm{kBtu} / \mathrm{sf} / \mathrm{yr})\end{array}$ \\
\hline Residential & 11.3 & 15.7 & 54.3 & 10.5 & 13.4 & 49.4 \\
\hline Nonresidential & 8.8 & 6.29 & 36.3 & 8.1 & 6.31 & 34.1 \\
\hline Semiheated & 4.11 & 18.54 & 32.5 & 4.05 & 17.48 & 31.3 \\
\hline
\end{tabular}

Table 5: Utility Cost and Environmental Impact Summary

\begin{tabular}{|c|c|c|c|c|c|c|c|c|}
\hline \multicolumn{9}{|c|}{ Cost and Environmental Impact } \\
\hline \multirow{3}{*}{$\begin{array}{l}\text { Building } \\
\text { Prototype }\end{array}$} & \multicolumn{6}{|c|}{ Utility Cost (\$/yr) } & \multicolumn{2}{|c|}{$\begin{array}{c}\mathrm{CO}_{2} \text { Emission } \\
(\mathrm{kg} / \mathrm{yr})\end{array}$} \\
\hline & \multicolumn{3}{|c|}{2006 IECC } & \multicolumn{3}{|c|}{2009 IECC } & \multirow{2}{*}{$\begin{array}{l}2006 \\
\text { IECC }\end{array}$} & \multirow{2}{*}{$\begin{array}{c}2009 \\
\text { IECC }\end{array}$} \\
\hline & Electricity & Gas & Total & Electricity & Gas & Total & & \\
\hline Residential & 28,532 & 2,727 & 31,259 & 26,485 & 2,357 & 28,842 & 294,162 & 271,982 \\
\hline Nonresidential & 24,434 & 1,387 & 25,822 & 22,775 & 1,390 & 24,165 & 347,805 & 323,391 \\
\hline Semiheated & 11,521 & 3,326 & 14,846 & 11,318 & 3,154 & 14,472 & 200,906 & 195,841 \\
\hline
\end{tabular}




\section{Conclusions}

The current buildings in Kansas City, MO are complying with the 2006 IECC commercial building requirements. Table 6 shows the percentage savings of energy, cost and environmental impacts reductions if these are built to comply with the 2009 IECC.

Table 6: Energy, Utility Cost and Environmental Reduction (percentage)

\begin{tabular}{|c|c|c|c|c|c|c|c|}
\hline \multicolumn{8}{|c|}{ Percentage Savings- 2006 IECC vs. 2009 IECC } \\
\hline \multirow[b]{2}{*}{$\begin{array}{l}\text { Building } \\
\text { Prototype }\end{array}$} & \multicolumn{3}{|c|}{ Energy Savings } & \multicolumn{3}{|c|}{ Utility Cost Savings } & \multirow[b]{2}{*}{$\begin{array}{c}\mathrm{CO}_{2} \\
\text { Emission } \\
\text { Savings } \\
\end{array}$} \\
\hline & $\begin{array}{c}\text { Electricity } \\
\text { Savings } \\
(\%) \\
\end{array}$ & $\begin{array}{c}\text { Natural Gas } \\
\text { Savings } \\
(\%) \\
\end{array}$ & $\begin{array}{c}\text { Total } \\
\text { Energy } \\
\text { Savings } \\
(\%) \\
\end{array}$ & $\begin{array}{c}\text { Electricity } \\
\text { Cost } \\
\text { Savings } \\
(\%) \\
\end{array}$ & $\begin{array}{c}\text { Natural } \\
\text { Gas Cost } \\
\text { Savings } \\
(\%)\end{array}$ & $\begin{array}{c}\text { Total } \\
\text { Utility } \\
\text { Cost } \\
\text { Savings } \\
(\%)\end{array}$ & \\
\hline Residential & $7.1 \%$ & $18.8 \%$ & $9.0 \%$ & $7.2 \%$ & $13.6 \%$ & $7.7 \%$ & $7.54 \%$ \\
\hline Nonresidential & $7.4 \%$ & $-0.3 \%$ & $6.1 \%$ & $6.8 \%$ & $-0.2 \%$ & $6.4 \%$ & $7.02 \%$ \\
\hline Semiheated & $1.4 \%$ & $5.8 \%$ & $3.9 \%$ & $1.8 \%$ & $5.2 \%$ & $2.5 \%$ & $2.52 \%$ \\
\hline
\end{tabular}

Based on the analysis, it can be observed that:

- Multifamily residential buildings built to the 2009 IECC would save $9 \%$ energy and save $7.7 \%$ energy cost compared to the 2006 IECC; and reduce $\mathrm{CO}_{2}$ emissions by $7.54 \%$.

- Nonresidential buildings built to the 2009 IECC save $6.1 \%$ energy, reduce $6.4 \%$ in energy cost, and $7.02 \%$ in $\mathrm{CO}_{2}$ emissions.

- The IECC does not have a separate set of envelope requirements for semiheated spaces and hence the nonresidential requirements are used in the analysis. Semiheated warehouse buildings have significantly different building occupancy and operational characteristics compared to other nonresidential buildings, and the analysis shows energy savings of $3.9 \%$ and cost savings of $2.5 \%$, with $\mathrm{CO}_{2}$ emission reduction of $2.52 \%$. 
Appendix A

Detailed Comparison of Code Requirements 



\title{
Appendix A - Detailed Comparison of Code Requirements
}

\author{
Table A.1: Comparison of Code Requirements
}

\begin{tabular}{|c|c|c|}
\hline \multicolumn{3}{|l|}{ Climate Zone 4} \\
\hline Topic & 2006 IECC & 2009 IECC \\
\hline $\begin{array}{l}\text { Design by } \\
\text { acceptable } \\
\text { practice for } \\
\text { commercial } \\
\text { buildings }\end{array}$ & $\begin{array}{l}\text { Code requirements for commercial buildings } \\
\text { contained in Chapter } 5 \text { resulting from the } \\
\text { replacement of Chapters } 4,5 \text { and } 6 \text { with } \\
\text { Chapter } 4 \text { and the elimination of Chapter } 7 \\
\text { from the IECC. }\end{array}$ & $\begin{array}{l}\text { Requires that the code user must demonstrate } \\
\text { compliance with Chapter 5, of the IECC in its } \\
\text { entirety or ASHRAE } 90.1-2007 \text { but cannot } \\
\text { mix compliance approaches on the same } \\
\text { project. Added a comparable assembly U- } \\
\text { factor table to correspond to the R-value } \\
\text { requirements in Table } 502.2(1) \text {. }\end{array}$ \\
\hline $\begin{array}{l}\text { ASHRAE/IESNA } \\
\text { reference }\end{array}$ & References ASHRAE/IESNA 90.1-2004 & References ASHRAE 90.1-2007 \\
\hline $\begin{array}{l}\text { Opaque and } \\
\text { fenestration } \\
\text { requirements }\end{array}$ & $\begin{array}{l}\text { Allows buildings up to } 40 \% \text { of the window } \\
\text { area to gross above-grade wall area. } \\
\text { Buildings that exceed this level are to use } \\
90.1-2004 \text { or Section } 506 \text {. }\end{array}$ & $\begin{array}{l}\text { Expands Table } 502.2(1) \text { to include a separate } \\
\text { category for high-rise residential and } \\
\text { commercial occupancies. Increases the } \\
\text { insulation requirements for both high-rise } \\
\text { residential and commercial in several climate } \\
\text { zones. }\end{array}$ \\
\hline Moisture control & $\begin{array}{l}\text { Requires vapor retarders to be installed in } \\
\text { unvented framed cavities in climate zones } \\
\text { greater than } 3 \text {. }\end{array}$ & $\begin{array}{l}\text { Defines a vapor retarder based on Class } \\
\text { (Type 1-3) and allows for the use of latex } \\
\text { paint as a vapor retarder based on siding type } \\
\text { and climate zone. }\end{array}$ \\
\hline $\begin{array}{l}\text { Metal building } \\
\text { walls }\end{array}$ & $\begin{array}{l}\text { Provides a description for meeting the metal } \\
\text { building wall requirements }\end{array}$ & $\begin{array}{l}\text { Adds additional descriptions for metal } \\
\text { building walls }\end{array}$ \\
\hline Roof assembly & $\begin{array}{l}2006 \text { IECC prohibits counting insulation } \\
\text { placed on a suspended ceiling and counting it } \\
\text { toward compliance with the roof R-value } \\
\text { requirement. }\end{array}$ & $\begin{array}{l}\text { Adds additional assembly descriptions for } \\
\text { metal roof systems }\end{array}$ \\
\hline Skylights & $\begin{array}{l}\text { Skylight U-factor based on climate zone and } \\
\text { material (either glass or plastic). Maximum } \\
\text { SHGC also required for skylights. Skylight } \\
\text { percentage limited to } 3 \% \text { of gross roof area. }\end{array}$ & $\begin{array}{l}\text { Consolidated the U-factor and SHGC } \\
\text { requirements for skylights into one skylight } \\
\text { category. Reduced (made more stringent) the } \\
\text { U-factor and SHGC requirements. }\end{array}$ \\
\hline $\begin{array}{l}\text { HVAC } \\
\text { equipment } \\
\text { performance } \\
\text { requirements }\end{array}$ & $\begin{array}{l}\text { Air conditioners, air cooled }<65,000 \mathrm{Btu} / \mathrm{h} \\
\text { required SEER } 13.0 \text { for split systems. }\end{array}$ & $\begin{array}{l}\text { Allows for alternative for water-cooled } \\
\text { centrifugal water-chilling package efficiency. } \\
\text { Revises equipment efficiency tables for } \\
\text { water-chilling packages. }\end{array}$ \\
\hline $\begin{array}{l}\text { Snow melt } \\
\text { controls }\end{array}$ & None & $\begin{array}{l}\text { Requires snow melt controls on all snow melt } \\
\text { equipment installed as part of a commercial } \\
\text { project. }\end{array}$ \\
\hline $\begin{array}{l}\text { Demand control } \\
\text { ventilation }\end{array}$ & None & $\begin{array}{l}\text { Requires demand control ventilation for } \\
\text { spaces larger than } 500 \mathrm{ft}^{2} \text { with an average } \\
\text { occupant load of } 40 \text { people per } 1000 \mathrm{ft}^{2} .\end{array}$ \\
\hline
\end{tabular}


Table A.1: Comparison of Code Requirements (continued)

\begin{tabular}{|c|c|c|}
\hline \multicolumn{3}{|l|}{ Climate Zone 4} \\
\hline Topic & 2006 IECC & 2009 IECC \\
\hline $\begin{array}{l}\text { Energy recovery } \\
\text { ventilation }\end{array}$ & $\begin{array}{l}\text { Requires an energy recovery ventilation } \\
\text { system for systems of } 5,000 \mathrm{cfm} \text { or greater } \\
\text { and a minimum outside air supply of } 70 \% \text { or } \\
\text { greater of the design supply air quantity. } \\
\text { Several exceptions. }\end{array}$ & $\begin{array}{l}\text { Removed the exception for laboratory fume } \\
\text { hood systems with a total exhaust rate of } \\
15,000 \mathrm{cfm} \text { or less. }\end{array}$ \\
\hline $\begin{array}{l}\text { Duct and plenum } \\
\text { insulation and } \\
\text { sealing }\end{array}$ & $\begin{array}{l}\text { Requires minimum duct insulation R-value of } \\
5 \text { for ducts in unconditioned space and R- } 8 \\
\text { outside the building. Requires approved } \\
\text { sealing for low, medium or high pressure duct } \\
\text { systems. Specifies UL } 181 \text { labeling for } \\
\text { specific duct connections. Requires maximum } \\
\text { duct leakage rate of } 6.0 \text { for high pressure duct } \\
\text { systems }\end{array}$ & $\begin{array}{l}\text { References the } 2009 \text { International Mechanical } \\
\text { Code for air sealing requirements. }\end{array}$ \\
\hline $\begin{array}{l}\text { HVAC piping } \\
\text { insulation }\end{array}$ & $\begin{array}{l}\text { Requires piping used to convey "conditioned" } \\
\text { fluids to be insulated. Includes some } \\
\text { exceptions. }\end{array}$ & $\begin{array}{l}\text { Adds an exception for factory-installed piping } \\
\text { within room fan-coils and unit ventilators. } \\
\text { Increase piping insulation thickness by } 1 / 2 \text { inch } \\
\text { for piping } \leq 1.5 \text { inch. }\end{array}$ \\
\hline $\begin{array}{l}\text { Simple system } \\
\text { economizers }\end{array}$ & $\begin{array}{l}\text { Requires economizers for all cooling systems } \\
\text { for systems } \geq 54,000 \mathrm{Btu} / \mathrm{h} \text {. No exceptions } \\
\text { for economizers in Climate Zones } 5 \mathrm{~b} \text { and } 6 \mathrm{~b} \text {. }\end{array}$ & $\begin{array}{l}\text { Requires systems greater than } 54,000 \mathrm{Btu} / \mathrm{h} \text { in } \\
\text { hot humid climates (Zone A) to meet the } \\
\text { economizer requirements for Climate Zone } 3 \\
\text { and above. Eliminates the category for } \\
\text { systems } \geq 135,000 \mathrm{Btu} / \mathrm{h} \text { and sets the } \\
\text { threshold for requiring an economizer to } \\
54,000 \mathrm{Btu} / \mathrm{h} \text { for all systems. }\end{array}$ \\
\hline $\begin{array}{l}\text { Fan power } \\
\text { limitations }\end{array}$ & None & $\begin{array}{l}\text { Requires HVAC fan systems greater than } 5 \mathrm{hp} \\
\text { to meet maximum fan power horsepower } \\
\text { requirements. }\end{array}$ \\
\hline $\begin{array}{l}\text { Hydronic (water } \\
\text { loop) heat pump } \\
\text { systems. }\end{array}$ & $\begin{array}{l}\text { Provides requirements for the use of heat } \\
\text { injection and heat rejection into the heat pump } \\
\text { loop. Places requirements for bypassing the } \\
\text { cooling tower when it is not needed. }\end{array}$ & $\begin{array}{l}\text { Reorganizes the code provision to make it } \\
\text { more understandable. Splits the requirements } \\
\text { for bypassing the cooling tower when no heat } \\
\text { rejection is needed based on climate zone. }\end{array}$ \\
\hline $\begin{array}{l}\text { Supply air } \\
\text { temperature reset } \\
\text { controls }\end{array}$ & None & $\begin{array}{l}\text { Requires controls to be placed on systems } \\
\text { serving multiple zones to be able to reset the } \\
\text { supply air temperature by } 25 \% \text { based on the } \\
\text { supply air temperature and the room } \\
\text { temperature. }\end{array}$ \\
\hline $\begin{array}{l}\text { Efficient lighting } \\
\text { in dwelling units }\end{array}$ & None & $\begin{array}{l}\text { Requires at least } 50 \% \text { of the permanently } \\
\text { connected lighting in dwelling units to be } \\
\text { fitted with high efficacy lamps. }\end{array}$ \\
\hline $\begin{array}{l}\text { Daylight zone } \\
\text { control }\end{array}$ & None & $\begin{array}{l}\text { Requires that connected lighting that is } \\
\text { installed in daylight zones be separately } \\
\text { switched from other lighting in the space. } \\
\text { Daylight zones are defined for spaces with } \\
\text { vertical fenestration and also for skylights. }\end{array}$ \\
\hline $\begin{array}{l}\text { Exterior lighting } \\
\text { controls }\end{array}$ & $\begin{array}{l}\text { Specifies the type of controls that can be used } \\
\text { to control exterior lighting not intended for } 24 \\
\text { hour operation. This includes: } \\
\text { - Lighting not designated for dusk-to-dawn } \\
\text { operation - astronomical time switch } \\
\text { - Lighting designated for dawn-to-dusk } \\
\text { - Operation - astronomical time switch or } \\
\text { photosensor. }\end{array}$ & $\begin{array}{l}\text { Allows for the use of a photocell in tandem } \\
\text { with a time clock or an astronomical time } \\
\text { clock for exterior lighting systems that are not } \\
\text { designed to stay on from dusk to dawn. } \\
\text { Eliminates the lighting control exemption for } \\
\text { lights that need to remain on for reasons that } \\
\text { pertain to safety, security or eye adaptation. }\end{array}$ \\
\hline
\end{tabular}


Table A.1: Comparison of Code Requirements (continued)

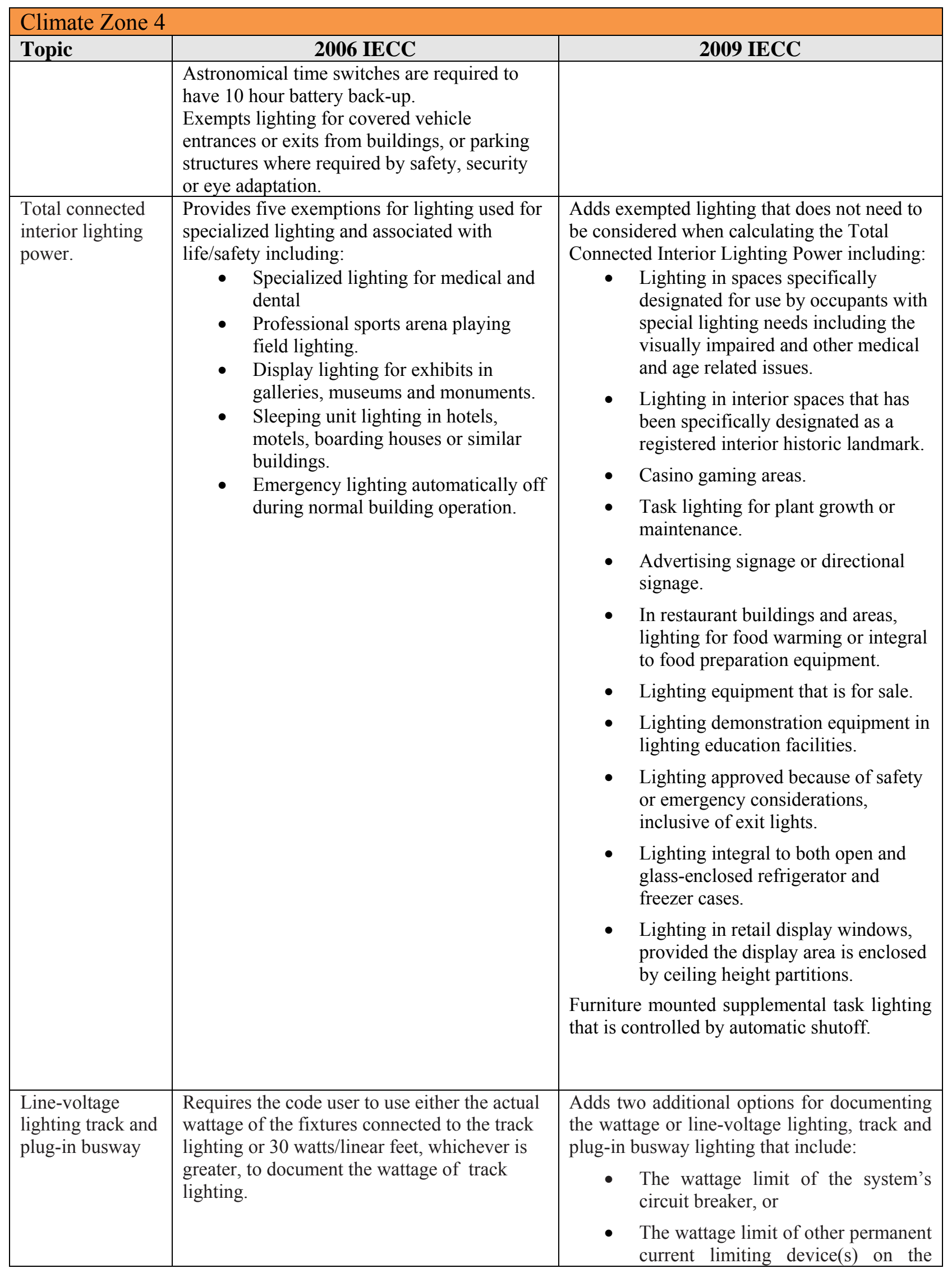


Table A.1: Comparison of Code Requirements (continued)

\begin{tabular}{|c|c|c|}
\hline \multicolumn{3}{|l|}{ Climate Zone 4} \\
\hline Topic & 2006 IECC & 2009 IECC \\
\hline & & system. \\
\hline $\begin{array}{l}\text { Interior lighting } \\
\text { power. }\end{array}$ & $\begin{array}{l}\text { Provides a signal column of lighting power } \\
\text { densities for all occupancy types that can be } \\
\text { used for either a whole building or tenant area } \\
\text { or portion of building approach. Reduces the } \\
\text { lighting power densities for a portion of the } \\
\text { occupancies, e.g., Office }\left(1.0 \mathrm{~W} / \mathrm{ft}^{2}\right) \text { and } \\
\text { Retail }\left(1.5 \mathrm{~W} / \mathrm{ft}^{2}\right) \\
\text { Eliminates the increased lighting allowances } \\
\text { for visual display terminals, decorative } \\
\text { lighting and emergency, recovery, medical } \\
\text { supply and pharmacy space. } \\
\text { Provides an additional } 1.6 \mathrm{~W} / \mathrm{ft}^{2} \text { for general } \\
\text { merchandise display lighting for up to } \\
50 \% \text { of the resale floor area and } 3.9 \mathrm{~W} / \mathrm{ft}^{2} \text { for } \\
\text { the actual shelf or case area for displaying } \\
\text { jewelry, china and silver. }\end{array}$ & $\begin{array}{l}\text { Revises the display lighting allowances to the } \\
\text { following: } \\
\text { Calculate the additional lighting power as } \\
\text { follows: } \\
\text { - Additional Interior Lighting Power } \\
\text { Allowance }=1000 \text { watts }+(\text { Retail } \\
\left.\text { Area } 1 \times 0.6 \mathrm{~W} / \mathrm{ft}^{2}\right)+(\text { Retail Area } 2 \\
\left.\times 0.6 \mathrm{~W} / \mathrm{ft}^{2}\right)+(\text { Retail Area } 3 \times 1.4 \\
\left.\mathrm{W} / \mathrm{ft}^{2}\right)+\left(\text { Retail Area } 4 \times 2.5 \mathrm{~W} / \mathrm{ft}^{2}\right), \\
\text { Where: } \\
\text { - Retail Area } 1=\text { the floor area for all } \\
\text { products not listed in retail area } 2,3 \\
\text { or } 4 . \\
\text { - Retail Area } 2=\text { the floor area used } \\
\text { for the sale of vehicles, sporting } \\
\text { goods and small electronics. } \\
\text { Retail Area } 3=\text { the floor area used } \\
\text { for the sale of furniture, clothing, } \\
\text { cosmetics and artwork. } \\
\text { Retail Area } 4=\text { the floor area used } \\
\text { for the sale of jewelry, crystal, and } \\
\text { china. }\end{array}$ \\
\hline Exterior lighting & $\begin{array}{l}\text { Requires all exterior lighting greater than } 100 \\
\text { watts to have a minimum efficacy of } 60 \\
\text { lumens per watt unless that lighting is } \\
\text { controlled by a motion sensor or is exempted. } \\
\text { Requires lighting budgets for all exterior } \\
\text { lighting. Includes categories for "tradable } \\
\text { surfaces" and "nontradable" surfaces. Limits } \\
\text { the total wattage that can be installed on the } \\
\text { exterior of commercial buildings. }\end{array}$ & $\begin{array}{l}\text { Creates exterior lighting zones for exterior } \\
\text { lighting based on lighting need. Exterior } \\
\text { lighting allowances are defined by the } \\
\text { following lighting zones with the highest } \\
\text { lighting levels allowed in Zone } 4 \text { : } \\
\text { Zone 1: Developed areas of National Parks, } \\
\text { State Parks, Forest Land, and Rural areas } \\
\text { Zone 2: Areas predominantly consisting of } \\
\text { residential zoning, neighborhood business } \\
\text { districts, light industrial with limited } \\
\text { nighttime use and residential mixed use areas } \\
\text { Zone 3: All other areas } \\
\text { Zone 4: High activity commercial districts in } \\
\text { major metropolitan areas as designated by the } \\
\text { local land use planning authority. } \\
\text { A base lighting allowance is allowed for each } \\
\text { lighting zone - from } 500 \text { watts to } 1,300 \text { watts } \\
\text { - for Zones } 1 \text { to 4, respectively. }\end{array}$ \\
\hline
\end{tabular}




\section{Appendix B}

\section{Prototype Building Descriptions}





\section{Appendix B - Prototype Building Descriptions}

Table B.1: Residential Prototype Building Characteristics

\begin{tabular}{|c|c|}
\hline \multicolumn{2}{|c|}{ Multifamily Building Characteristics } \\
\hline \multicolumn{2}{|l|}{ General } \\
\hline Building Type & Mid-rise Apartment \\
\hline Total Floor Area & $33,700 \mathrm{sqft}$ \\
\hline Building Shape & Rectangle (152 ft x $55.5 \mathrm{ft})$ \\
\hline Aspect Ratio & 2.74 \\
\hline Number of Floors & 4 \\
\hline Window Fraction & $15 \%$ \\
\hline Window Shading & None \\
\hline Thermal Zoning & $\begin{array}{l}\text { Ground floor: } 7 \text { apartments and } 1 \text { lobby with equivalent apartment area } \\
\text { Floors above: } 8 \text { apartments with corridor in center } \\
\text { Zone depth is } 25 \mathrm{ft} \text { for each apartment from side walls and each apt is } \\
25 \mathrm{ft} \times 38 \mathrm{ft}\left(950 \mathrm{ft}^{2}\right) \text {. }\end{array}$ \\
\hline Floor to Floor Height (feet) & $10 \mathrm{ft}$ \\
\hline Floor to Ceiling Height (feet) & $10 \mathrm{ft}$ (no drop down ceiling modeled) \\
\hline Glazing Sill Height (feet) & $3 \mathrm{ft}$. (14 ft wide $\mathrm{x} 4 \mathrm{ft}$ high) \\
\hline Exterior Walls & Steel-framed wall \\
\hline Roof & Insulation entirely above deck, metal deck roof \\
\hline Foundation & 8 in. concrete slab-on-grade floors (unheated) \\
\hline Interior Partitions & $2 \times 4$ uninsulated stud wall \\
\hline Internal Mass & 6 in. standard wood $\left(16.6 \mathrm{lb} / \mathrm{ft}^{2}\right)$ \\
\hline Infiltration & $\begin{array}{l}\text { Peak: } 0.2016 \mathrm{cfm} / \mathrm{sf} \text { of above-grade exterior wall surface area (when fans } \\
\text { turn off) } \\
\text { Off Peak: } 25 \% \text { of peak infiltration rate (when fans turn on) }\end{array}$ \\
\hline \multicolumn{2}{|l|}{ Internal Loads \& Schedules } \\
\hline Lighting Power Density (W/ft²) & $\begin{array}{l}\text { Apartment units: } 0.36 \mathrm{~W} / \mathrm{ft}^{2} \\
\text { Corridor: } 0.5 \mathrm{~W} / \mathrm{ft}^{2} \\
\text { Office: } 1.1 \mathrm{~W} / \mathrm{ft}^{2}\end{array}$ \\
\hline Plug Load Power Density $\left(\mathrm{W} / \mathrm{ft}^{2}\right)$ & Building average, $0.62 \mathrm{~W} / \mathrm{ft}^{2}$ \\
\hline Occupancy & 78 Total (2.5 person per apartment unit) \\
\hline
\end{tabular}

B.1 
Table B.1: Residential Prototype Building Characteristics (continued)

\begin{tabular}{|c|c|}
\hline HVAC & \\
\hline System Type & \\
\hline Heating Type & Gas furnace inside the packaged air-conditioning unit \\
\hline Cooling Type & Split DX System \\
\hline Distribution and Terminal Units & Constant volume \\
\hline HVAC Control & \\
\hline Thermostat Setpoint & $75^{\circ} \mathrm{F}$ cooling $/ 70^{\circ} \mathrm{F}$ heating \\
\hline Thermostat Setback & No setback \\
\hline Supply Air Temperature & Maximum $110^{\circ} \mathrm{F}$, Minimum $52^{\circ} \mathrm{F}$ \\
\hline Ventilation & $20 \mathrm{cfm} /$ person \\
\hline Demand Control Ventilation & No \\
\hline Energy Recovery & No \\
\hline Supply Fan & \\
\hline Fan Type & Constant air volume \\
\hline Supply Fan Total Efficiency (\%) & $70 \%$ \\
\hline Supply Fan Pressure Drop & 0.2 in. Water \\
\hline Service Water Heating & \\
\hline SWH Type & Storage tank \\
\hline Fuel Type & Electricity \\
\hline Thermal Efficiency (\%) & $100 \%$ \\
\hline Tank Volume (gal) & 20 (one per unit) \\
\hline Water Temperature Setpoint & $120^{\circ} \mathrm{F}$ \\
\hline Misc. & \\
\hline Exterior Lighting & $2075 \mathrm{~W}$ \\
\hline
\end{tabular}


Table B.2: Nonresidential Prototype Building Characteristics

\begin{tabular}{|c|c|}
\hline \multicolumn{2}{|r|}{ Medium Office Building Characteristics } \\
\hline \multicolumn{2}{|l|}{ General } \\
\hline Building Prototype & Medium Office \\
\hline Total Floor Area & $53,600 \mathrm{sf}$ \\
\hline Building Shape & Rectangle (163.8 ft x $109.2 \mathrm{ft})$ \\
\hline Aspect Ratio & 1.5 \\
\hline Number of Floors & 3 \\
\hline Window Fraction & $33 \%$ \\
\hline Shading Geometry & None \\
\hline Thermal Zoning & $\begin{array}{l}\text { Perimeter zone depth: } 15 \mathrm{ft} \text {. } \\
\text { Each floor has four perimeter zones and one core zone. } \\
\text { Percentages of floor area: Perimeter } 40 \% \text {, Core } 60 \%\end{array}$ \\
\hline Floor to Floor Height (feet) & $13 \mathrm{ft}$ \\
\hline Floor to Ceiling Height (feet) & $9 \mathrm{ft},(4 \mathrm{ft}$ above-ceiling plenum) \\
\hline Glazing Sill Height (feet) & $3.35 \mathrm{ft}$ (top of the window is $7.64 \mathrm{ft}$ high with $4.29 \mathrm{ft}$ high glass) \\
\hline Exterior Walls & Steel-framed wall \\
\hline Roof & Insulation entirely above deck, metal deck roof \\
\hline Foundation & 8 in. concrete slab-on-grade floors (unheated) \\
\hline Interior Partitions & $2 \times 4$ uninsulated stud wall \\
\hline Internal Mass & 6 inches standard wood $\left(16.6 \mathrm{lb} / \mathrm{ft}^{2}\right)$ \\
\hline Infiltration & $\begin{array}{l}\text { Peak: } 0.2016 \mathrm{cfm} / \mathrm{sf} \text { of above-grade exterior wall surface area (when fans turn off) } \\
\text { Off Peak: } 25 \% \text { of peak infiltration rate (when fans turn on) }\end{array}$ \\
\hline \multicolumn{2}{|l|}{ Internal Loads \& Schedules } \\
\hline Lighting Power Density $\left(\mathrm{W} / \mathrm{ft}^{2}\right)$ & Building average, 1.00 \\
\hline Plug Load Power Density $\left(\mathrm{W} / \mathrm{ft}^{2}\right)$ & Building average, all zones 0.75 \\
\hline Occupancy & 268 Total (5 persons/1000 sf) \\
\hline
\end{tabular}


Table B.2: Nonresidential Prototype Building Characteristics (continued)

\begin{tabular}{|c|c|}
\hline \multicolumn{2}{|l|}{ HVAC } \\
\hline \multicolumn{2}{|l|}{ System Type } \\
\hline Heating Type & Gas furnace inside the packaged air-conditioning unit \\
\hline Cooling Type & Packaged air-conditioning unit \\
\hline Distribution and Terminal Units & $\begin{array}{l}\text { VAV terminal box with damper and electric reheating coil } \\
\text { Zone control type: minimum supply air at } 30 \% \text { of the zone design peak supply air. }\end{array}$ \\
\hline \multicolumn{2}{|l|}{ HVAC Control } \\
\hline Thermostat Setpoint & $75^{\circ} \mathrm{F}$ cooling $/ 70^{\circ} \mathrm{F}$ heating \\
\hline Thermostat Setback & $80^{\circ} \mathrm{F}$ cooling $/ 60^{\circ} \mathrm{F}$ heating \\
\hline Supply Air Temperature & Maximum $110^{\circ} \mathrm{F}$, Minimum $52^{\circ} \mathrm{F}$ \\
\hline Ventilation & $20 \mathrm{cfm} /$ person \\
\hline Demand Control Ventilation & No \\
\hline Energy Recovery & No \\
\hline \multicolumn{2}{|l|}{ Supply Fan } \\
\hline Fan Type & Variable air volume \\
\hline Supply Fan Total Efficiency (\%) & $57 \%$ to $60 \%$ depending on the fan motor size \\
\hline Supply Fan Pressure Drop & 4 in. -6.3 in. water \\
\hline \multicolumn{2}{|l|}{ Service Water Heating } \\
\hline SWH Type & Storage tank \\
\hline Fuel Type & Natural gas \\
\hline Thermal Efficiency (\%) & $80 \%$ \\
\hline Tank Volume (gal) & 260 \\
\hline Water Temperature Setpoint & $120^{\circ} \mathrm{F}$ \\
\hline \multicolumn{2}{|l|}{ Misc. } \\
\hline \multicolumn{2}{|l|}{ Exterior Lighting } \\
\hline Peak Power & $2730 \mathrm{~W}$ \\
\hline
\end{tabular}


Table B.3: Semiheated Prototype Building Characteristics

\begin{tabular}{|c|c|}
\hline \multicolumn{2}{|c|}{ Large Warehouse Building Characteristics } \\
\hline \multicolumn{2}{|l|}{ General } \\
\hline $\begin{array}{l}\text { Building Type (Principal Building } \\
\text { Function) }\end{array}$ & Non-refrigerated warehouse \\
\hline Total Floor Area & $52,045 \mathrm{ft}^{2}$ \\
\hline Building Shape & Rectangle \\
\hline Aspect Ratio & 2.2 \\
\hline Number of Floors & 1 \\
\hline Window Fraction & $\begin{array}{l}\text { Storage Area: No windows; } \\
\text { Office Area: } 12 \% \text { veiw windows; } \\
\text { Overall: } 0.71 \% \text {; } \\
\text { North: } 0.76 \% \text {; } \\
\text { East: } 0.0 \% \text {; } \\
\text { South: } 0.0 \% \text {; } \\
\text { West: } 2.86 \% \\
\end{array}$ \\
\hline Shading Geometry & None \\
\hline Thermal Zoning & $\begin{array}{l}\text { Office: } 2549.76 \mathrm{ft}^{2} \\
\text { Fine Storage: } 14,998.54 \mathrm{ft}^{2} \\
\text { Bulk Storage: } 34496.61 \mathrm{ft}^{2} \text { (semi-heated) }\end{array}$ \\
\hline Floor to Floor Height & $28 \mathrm{ft}$ \\
\hline Floor to Ceiling Height (feet) & $14 \mathrm{ft}$ (for the office area only) \\
\hline Glazing Sill Height & $3 \mathrm{ft}$ (top of the window is $8-\mathrm{ft}$ high) \\
\hline Exterior Walls & Metal Building \\
\hline Roof & Metal Building \\
\hline Foundation & 6 in. concrete slab-on-grade \\
\hline Interior Partitions & Double layer of gypsum board with an exterior layer of stucco \\
\hline Internal Mass & $\begin{array}{l}\text { Defined as material with properties: } \\
\text { density: } 12.5 \mathrm{lb} / \mathrm{ft}^{2} \\
\text { thickness: } 8 \mathrm{ft} \\
\text { Internal mass surface area: } 64889.66 \mathrm{ft}^{2}\end{array}$ \\
\hline Infiltration & $\begin{array}{l}\text { Office: } 0.078 \mathrm{cfm} / \mathrm{ft}^{2} \\
\text { Fine storage: } 0.080 \mathrm{cfm} / \mathrm{ft}^{2} \\
\text { Bulk storage: } 4793.56 \mathrm{cfm}\end{array}$ \\
\hline \multicolumn{2}{|l|}{ Internal Loads \& Schedules } \\
\hline \multicolumn{2}{|l|}{ Lighting } \\
\hline Average Power Density $\left(\mathrm{W} / \mathrm{ft}^{2}\right)$ & $\begin{array}{l}\text { Fine and bulk area: } 0.80 \mathrm{~W} / \mathrm{ft}^{2} \text {; } \\
\text { Office area: } 1.00 \mathrm{~W} / \mathrm{ft}^{2}\end{array}$ \\
\hline Daylighting Controls & Daylight control: bulk storage area \\
\hline Occupancy Sensors & No \\
\hline Plug Load power density (W/ft $\left.{ }^{2}\right)$ & $\begin{array}{l}\text { Office: } 0.75 \mathrm{~W} / \mathrm{ft}^{2} \\
\text { Bulk storage: } 0.24 \mathrm{~W} / \mathrm{ft}^{2}\end{array}$ \\
\hline Occupancy & 5 (in the office) \\
\hline
\end{tabular}


Table B.3: Semi-heated Prototype Building Characteristics (continued)

\begin{tabular}{|c|c|}
\hline \multicolumn{2}{|l|}{ HVAC } \\
\hline \multicolumn{2}{|l|}{\begin{tabular}{l|l} 
System Type \\
\end{tabular}} \\
\hline Heating Type & Gas-fired furnace \\
\hline Cooling Type & DX cooling coil \\
\hline Distribution and Terminal Units & Direct uncontrolled air \\
\hline \multicolumn{2}{|l|}{ HVAC Control } \\
\hline Thermostat Setpoint & $\begin{array}{l}\text { Fine storage: } 80^{\circ} \mathrm{F} \text { cooling } / 60^{\circ} \mathrm{F} \text { heating; } \\
\text { Office area: } 75^{\circ} \mathrm{F} \text { cooling } / 70^{\circ} \mathrm{F} \text { heating; } \\
\text { Bulk storage: } 50^{\circ} \mathrm{F} \text { heating; }\end{array}$ \\
\hline Thermostat Setback & Office Area: $85^{\circ} \mathrm{F}$ Cooling $/ 60^{\circ} \mathrm{F}$ Heating \\
\hline Supply Air Temperature & Maximum $110^{\circ} \mathrm{F}$, Minimum $55^{\circ} \mathrm{F}$ \\
\hline Ventilation & $\begin{array}{l}\text { Bulk storage: } 80009 \mathrm{cfm} \text { (exhaust); } 2000 \mathrm{cfm} \text { (natural) } \\
\text { Office: } 0.085 \mathrm{cfm} / \mathrm{ft}^{2} \\
\text { Storage: } 0.06 \mathrm{cfm} / \mathrm{ft}^{2}\end{array}$ \\
\hline Demand Control Ventilation & No \\
\hline Energy Recovery & No \\
\hline \multicolumn{2}{|l|}{ Supply Fan } \\
\hline Fan Type & Constant air volume \\
\hline Supply Fan Total Efficiency (\%) & $\begin{array}{l}\text { Office area: fan efficiency } 54.6 \% \text {, motor efficiency } 84 \% \text {; } \\
\text { Fine storage: fan efficiency } 56.875 \% \text {, motor efficiency } 87.5 \text {; } \\
\text { Bulk storage unit heater: fan efficiency } 53.6 \% \text {, motor efficiency } 82.5 \%\end{array}$ \\
\hline Supply Fan Pressure Drop & $\begin{array}{l}\text { Office area: } 2.5 \text { in. water } \\
\text { Fine storage: } 2.5 \text { in. water } \\
\text { Bulk storage: } 0.2 \text { in. water }\end{array}$ \\
\hline \multicolumn{2}{|l|}{ Service Water Heating } \\
\hline SWH Type & Electric storage water heater \\
\hline Fuel Type & Electricity \\
\hline Thermal Efficiency (\%) & $100 \%$ \\
\hline Tank Volume (gal) & 20 \\
\hline Water Temperature Setpoint & $120^{\circ} \mathrm{F}$ \\
\hline \multicolumn{2}{|l|}{ Misc. } \\
\hline \begin{tabular}{l|l} 
Exterior Lighting Peak Power \\
\end{tabular} & 4800 watts \\
\hline
\end{tabular}




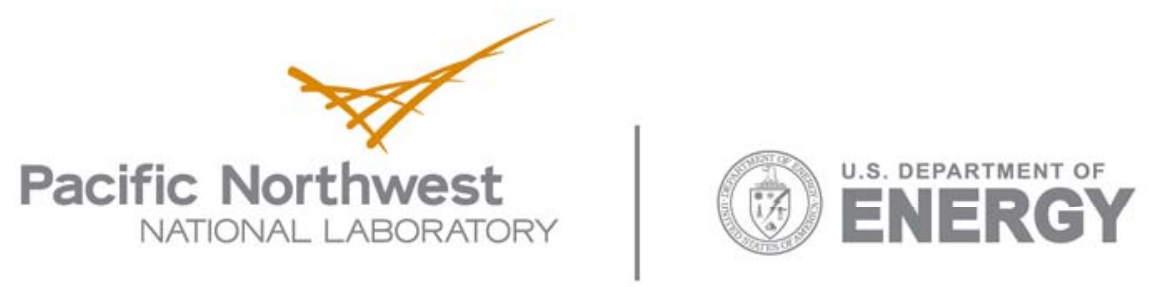

902 Battelle Boulevard

P.O. Box 999

Richland, WA 99352

1-888-375-PNNL (7665)

www.pnl.gov 